\title{
ANALISIS LOYALITAS KONSUMEN TUPPERWARE
}

\author{
Nurul Izzah \\ Institut Agama Islam Negeri Padangsidimpuan \\ Jalan T. Rizal Nurdin Km. 4,5 Sihitang, Padangsidimpuan \\ Email : nurulizzahlubis@gmail.com
}

\begin{abstract}
Abstrak,
Kualitas produk dan harga memiliki kaitan dengan loyalitas konsumen. Kualitas yproduk yang baik dan harga yang wajar akan meningkatkan loyalitas konsumen. Tujuan penelitian ini adalah untuk menganalisis pengaruh kualitas produk dan harga terhadap loyalitas konsumen Tupperware. Penelitian ini merupakan penelitian kuantitatif dengan menggunakan data primer dan sekunder yang diperoleh dari konsumen Tupperware di Padangsidimpuan Utara. Hasil estimasi menunjukkan bahwa terdapat pengaruh yang positif dan signifikan variabel kualitas produk terhadap variabel loyalitas konsumen Tupperware. Hasil estimasi juga menunjukkan bahwa tidak terdapat pengaruh variabel harga terhadap variabel loyalitas konsumen Tupperware.
\end{abstract}

Kata Kunci : Loyalitas Konsumen, Kualitas Produk, Harga, Regresi

\begin{abstract}
,
Product quality and price has a correlation with consumer loyalty. Good product quality and good price will increase loyality of consumen. The objective of the research was to analyze the influence of product quality and price to Tupperware consumer loyalty. The research was quantitative analytic with primer and secondary data from Tupperware consumen in North Padangsidimpuan. The result of the research showed that there was the positif influence of product quality variable to the variable Tupperware consumer loyalty. The result of the research also showed that there was not influence of price variable to the variable Tupperware consumer loyalty.
\end{abstract}

Keywords : Consumer Loyalty , Product Quality, Price, Regression 


\section{PENDAHULUAN}

Loyalitas konsumen terhadap suatu produk dipengaruhi oleh banyak hal. Diantaranya, kualtas produk, harga, desain, promosi, brand ambassador, dan lain-lain. Konsumen cenderung akan memiliki loyalitas yang tinggi terjhadap suatu pruduk jika produk tersebut berkualitas tinggi dengan kata lain produk tersebut mampu memberikan kepuasan yang diharapkan konsumen. Konsumen juga akan memiliki loyalitas jika harga yang ditawarkan produk terjangkau dan wajar menurut konsumen. Selain kualitas produk dan harga, faktor lain seperti desain dan promosi juga akan banyak mempegaruhi konsumen untuk terus menggunakan produk yang sama atau beralih ke merek lain.

Tupperware telah menjadi merek peralatan rumah tangga berbahan plastik yang sudah tidak asing lagi bagi masyarakat Indonesia. Mengingat minat masyarakat yang tinggi terhadap penggunaan peralatan rumah tangga berbahan plastik membuat banyak merek-merek lain bermunculan dengan membawa keunggulan-keunggulan masing-masing.

Di Indonesia, Tupperware telah resmi dipasarkan sejak tahun 1990. Produk Tupperware telah menembus berbagai kalangan di masyarakat dan memiliki lebih dari 190.ooo tenaga penjual independen.

Hingga saat ini, Tupperware di Indonesia telah banyak mendapat penghargaan. Pada tahun 2014, Tupperware telah menerima 10 penghargaan diantaranya ICSA Award 2014 (www.tupperware.co.id, 2018). ICSA adalah suatu program regular tahunan berupa pemberian penghargaan terhadap perusahaan-perusahaan berprestasi terbaik di Indonesia dalam hal memberikan kepuasaan pelanggan/ konsumen.

Selain berbagai penghargaan yang telah diperoleh Tupperware, tahun 2018 konsumen Tupperware menerima satu keunggulan lainnya dimana produk-produk Tupperware bisa digadaikan di PT. Pegadaian. PT. Pegadaian Indonesia menerima Tupperware untuk digadaikan dengan terlebih dahulu ditaksir nilainya oleh penaksir barang di outlet. Namun, tidak semua outlet menerima Tupperware untuk digadaikan, tergantung kepada pimpinan cabangnya. Gadai Tupperware termasuk dalam kategori pinjaman gadai kecil. Pinjaman terkecil dimulai dari RP. 50.000 hingga Rp. 500.000 dengan dengan bunga nol persen (www.ekonomi.kompas.com, 2018).

Jumlah konsumen Tupperware dari waktu ke waktu cenderung mengalami kenaikan yang cukup pesat. Hal ini disebabkan berbagai keunggulan yang dimiliki Tupperware. Konsumen tetap memilih produk Tupperware dan cenderung loyal untuk tetap menggunakannya meskipun banyak anggapan bahwa produk Tupperware harganya mahal. 
Meskipun demikian, konsumen loyal terhadap berbagai produk Tupperware mengingat kualitas produk yang ditawarkan memberikan kepuasaan yang tinggi kepada konsumen, sehingga peneliti mengambil tema penelitian yaitu "Analisis Loyalitas Konsumen

\section{Tupperware".}

Penelitian ini mencoba melihat keterkaitan variabel kualitas produk dan harga sebagai variabel independen dan variabel loyalitas konsumen sebagai variabel dependen. Berdasarkan hal tersebut, tujuan penelitian ini adalah : Untuk mengetahui pengaruh kualitas produk dan harga terhadap loyalitas konsumen Tupperware.

\section{TINJAUAN TEORITIK}

Loyalitas pelanggan adalah kesetiaan konsumen untuk terus menggunakan produk yang sama dari suatu perusahaan (Basu, 2009). Konsumen akan memiliki loyalitas yang tinggi terhadap suatu produk jika produk tersebut mampu memberikan kepuasaan yang tinggi kepada konsumen. Sebaliknya, produk ynag tidak mampu memberikan kepuasaan yang tinggi sesuai dengan harapan konsumen maka konsumen akan memiliki loyalitas yang rendah dan cenderung untuk beralih ke merek lain.

Loyalitas konsumen dipengaruhi leh banyak hal diantaranya harga produk dan kualias produk. Menurut Dharmamesta, loyalitas konsumen dipengaruhi oleh kualitas produk dan promosi (Dharmamesta dan Swasthu, 1999). Perusahaan yang sangat memperhatikan kualitas produk dan menawarkan harga yang sangat wajar akan lebih mudah mendapatkan konsumen yang loyal. Karena kualitas produk yang baik akan memberikan kepuasaan konsumen yang tinggi.

Kualitas produk adalah suatu nilai dari produk atau jasa, dimana nilai produk atau jasa sesuai dengan apa yang diharapkan atau melebihi apa yang dharapkan sehingga produk atau jasa tersebut dapat memenuhi kebutuhan pemakainya (Kotler dan Amstrong. 2000). Suatu produk dikatakan berkualitas jika produk tersebut mampu memberikan kepuasan sepenuhnya kepada konsumen. Kualitas produk dapat dianalisis dengan menggunakan delapan dimensi yaitu : a) performance, b) features, c) reability, d) durability, e) aesthetics, f) perceived quality, g) service ability, h) fit and finish.

Konsumen dalam memenuhi kebutuhan hidupnya tentu sangat memperhatikan kualitas produk. Hal ini dilakukan agar produk yang dibeli dapat memberikan manfaat bagi pemenuhan kebutuhan hidupnya. Islam juga mendorong individu agar membelanakan hartanya untuk membeli barang-barang yang baik dan halal dalam memenuhi kebutuhan hidupnya. Sesuai dengan Surat Al- Maidah ayat 88. 
Artinya : " dan makanlah makanan yang halal lagi baik dari apa yang Allah telah rezekikan kepadamu, dan bertaqwalah kepada Allah yang kamu beriman kepada-Nya."

Selain kualitas, harga juga merupakan faktor yang mempengaruhi loyalitas konsumen terhadap suatu produk. Harga merupakan salah satu penentu keberhasilan suatu perusahaan kaena harga menentukan seberapa besar keuntungan yang akan diperoleh perusahaan setelah produk tersebut terjual ke konsumen (Kurniawan, 2014). Perusahaan dalam menetapkan harga produk erat kaitannya dengan nlai produk yang akan dipertukarkan. Jika harga yang ditetapkan lebih tinggi dibandingkan nilai yang diperoleh konsumen maka tidak terjadi pertukaran.

Tujuan penentuan harga yaitu untuk memperoleh keuntungan yang optimal, membut perusahaan tetap bertahan, mencapa ROI, menguasai pasar, dan mempertahankan status Quo. Harga yang ditetapkan perusahaan akan sangat menentukan laku tidaknya suatu produk di pasar. Beberapa strategi yang dilakukan erkait penyesuaian harga diantaranya melalui diskon, potongan harga, dan penetapan promosi.

Di dalam Islam, setiap individu tidak berhak menetapkan harga kecuali terdapat kesepakatan antara si penjual dan si pembeli namun si penjual memiliki hak untuk meningkatkan harga denan tidak melampaui batas di luar rasional (Jajuli, 2016). Sebagaimana firman Allah SWT dalam surah An-Nisa ayat 29.

Artinya : "Hai orang-orang yang beriman, janganlah kamu saling memakan harta sesamamu dengan jalan yang batil, kecuali dengan jalan perniagaan yang berlaku dengan suka sama suka diantara kamu. Dan janganlah kamu membunuh dirimu. Sesungguhnya Allah adalah Maha Penyayang kepadamu”.

Beberapa penelitian terdahulu antara lain adalah penelitian oleh Nurullaili (2013) yang berjudul “ Analisis Faktor-Faktor yang Mempengaruhi Loyalitas Konsumen Tupperware (Studi Pada Konsumen Tupperware di Universitas Diponegoro)”. Hasil penelitiannya menyimpulkan bahwa loyalitas konsumen dipengaruhi variabel kualitas produk dan harga sebesar 73 persen dan sisanya dipengaruhi variabel lain diluar model. Kualitas produk Tupperware sudah sangat baik dengan berbagai desain, bentuk dan warna yang menarik.

Penelitian Vivil Yazia (2014) yang berjudul "Pengaruh Kualitas Produk, Harga dan Iklan terhadap Keputusan Pembelian Handphone Blackberry”. Hasil penelitian menyatakan bahwa variabel kualitas produkdan iklan berpengaruh terhadap keputusan pembelian. Sedangkan variabel harga tidak signifikan mempengaruhi keputusan pembelian. Blackberry sebaiknya meningkatkan kreativitas dalam mutu produk, harga dan iklan untuk mampu bersaing dengan handphone merek lain. 
Sedangkan menurut penelitian oleh Nur Achidah, dkk (2016) yang berjudul "Pengaruh Promosi, Harga, dan Desain terhadap Keputusan Pembelian Sepeda Motor Mio GT” Hasil penelitian menyatakan bahwa secara parsial dan secara simultan variabel promosi, harga dan desain berpengaruh secara signifikan terhdap keputusan pembelian. Ketiga varibel tersebut mempengaruhi keputusan pembelian sebesar 45, 3 persen.

Hipotesis yang diajukan dalam penelitian ini adalah diduga kualitas produk dan harga berpengaruh terhadap loyalitas konsumen Tupperware. Model hipotesis penelitian digambarkan sebagai berikut.

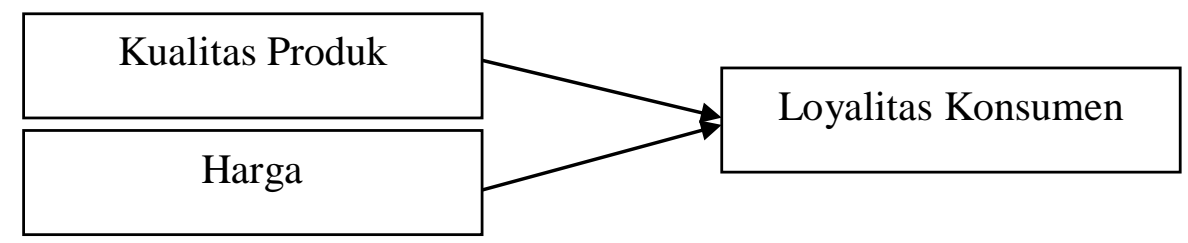

Gambar 1 : Model Hipotesis

\section{METODE PENELITIAN}

Populasi penelitian ini adalah masyarakat kampung jawa kecamatan Padangsidimpuan Utara yang menjadi pelanggan Tupperware. Untuk menentukan ukuran sampel, Suharsimi Arikunto menjelaskan bahwa subyek yang kurang dari 100 lebih baik diambil semua sehingga penelitiannya merupakan penelitian populasi. Selanjutnya jika jumlah subyeknya lebih besar dapat diambil antara 10-15 persen atau 20-25 persen atau lebih, tergantung setidak-tidaknya dari segi waktu, tenaga dan dana (Suharsimi Arikunto, 2006). Dengan demikian jumlah sampel dalam penelitian ini berjumlah 50 responden. Teknik pengambilan sampel yang digunakan yaitu purposive sampling dengan kriteria responden merupakan pelanggan Tupperware yang telah melakukan pembelian minimal sebanyak dua kali.

Data yang digunakan dalam penelitian ini terdiri dari data primer dan data sekunder. Data primer dikumpulkan melalui wawancara, dokumentasi dan kuesioner. Sedangkan datadata sekunder dikumpulkan melalui berbagai sumber yang telah didokumentasikan. Teknik analisis data yang digunakan yaitu regresi linier berganda. Formula yan digunakan sebagai berikut.

$$
\text { Loyalitas }=\beta_{o}+\beta_{1} \text { Kualitas }+\beta_{2} \text { Harga }+\mathbf{e}
$$

Dimana :

Loyalitas = Loyalitas konsumen

Kualitas = Kualitas Produk

Harga = Harga Produk

$\beta_{\mathrm{o}} \quad=$ Konstanta 


$$
\begin{array}{ll}
\beta_{1}, \beta_{2} & =\text { Koefisien } \\
\mathrm{e} & =\text { error term }
\end{array}
$$

\section{HASIL DAN PEMBAHASAN}

\section{Uji Asumsi Klasik}

\section{Normalitas}

Penelitian ini menggunakan metode One Sample Kolmogorov-Simirnov untuk mengetahui data berdistribusi normal atau tidak. Dalam hal ini, jika nilai signifikansi lebih dari 0,05 maka residual berdistribusi normal. Berdasarkan hasil pengujian data sebagaimana terlihat pada Tabel 1 dibawah ini diketahui bahwa nilai signifikansi (Asymp.Sig 2-Tailed) sebesar 0,624. Karena nilai signifikansi lebih besar dari o,05, maka nilai residual berdistribusi dengan normal.

Tabel 1. Hasil Uji Normalitas

\begin{tabular}{|c|c|c|}
\hline & & Unstandardized Residual \\
\hline \multicolumn{2}{|l|}{$\mathrm{N}$} & 50 \\
\hline \multirow[t]{2}{*}{ Normal Parameters ${ }^{a}$} & Mean & .0000000 \\
\hline & Std. Deviation & 2.53532932 \\
\hline \multirow{3}{*}{$\begin{array}{l}\text { Most Extreme } \\
\text { Differences }\end{array}$} & Absolute & .106 \\
\hline & Positive & .071 \\
\hline & Negative & -.106 \\
\hline \multicolumn{2}{|c|}{ Kolmogorov-Smirnov Z } & .752 \\
\hline \multicolumn{2}{|l|}{ Asymp. Sig. (2-tailed) } & .624 \\
\hline \multicolumn{2}{|c|}{ a. Test distribution is Normal. } & \\
\hline
\end{tabular}

One-Sample Kolmogorov-Smirnov Test

Sumber : Data penelitian, diolah

\section{Multikolinearitas}

Multikolinearitas artinya antar variabel independen yang terdapat dalam model regresi memiliki hubungan linier yang sempurna (koefisien korelasinya tinggi atau bahkan 1). Multikolinearitas dalam penelitian ini dideteksi dengan melihat nilai Tolerance dan Inflation Factor (VIF). Apabila nilai VIF kurang dari 10 dan Tolerance lebih dari 0.1 maka dinyatakan tida terjadi multikolinearitas (Ghozali, 2001). Hasil uji multikolinearitas dapat dilihat pada tabel berikut. 
Tabel 2. Hasil Uji Multikolinearitas

Coefficients $^{\text {a }}$

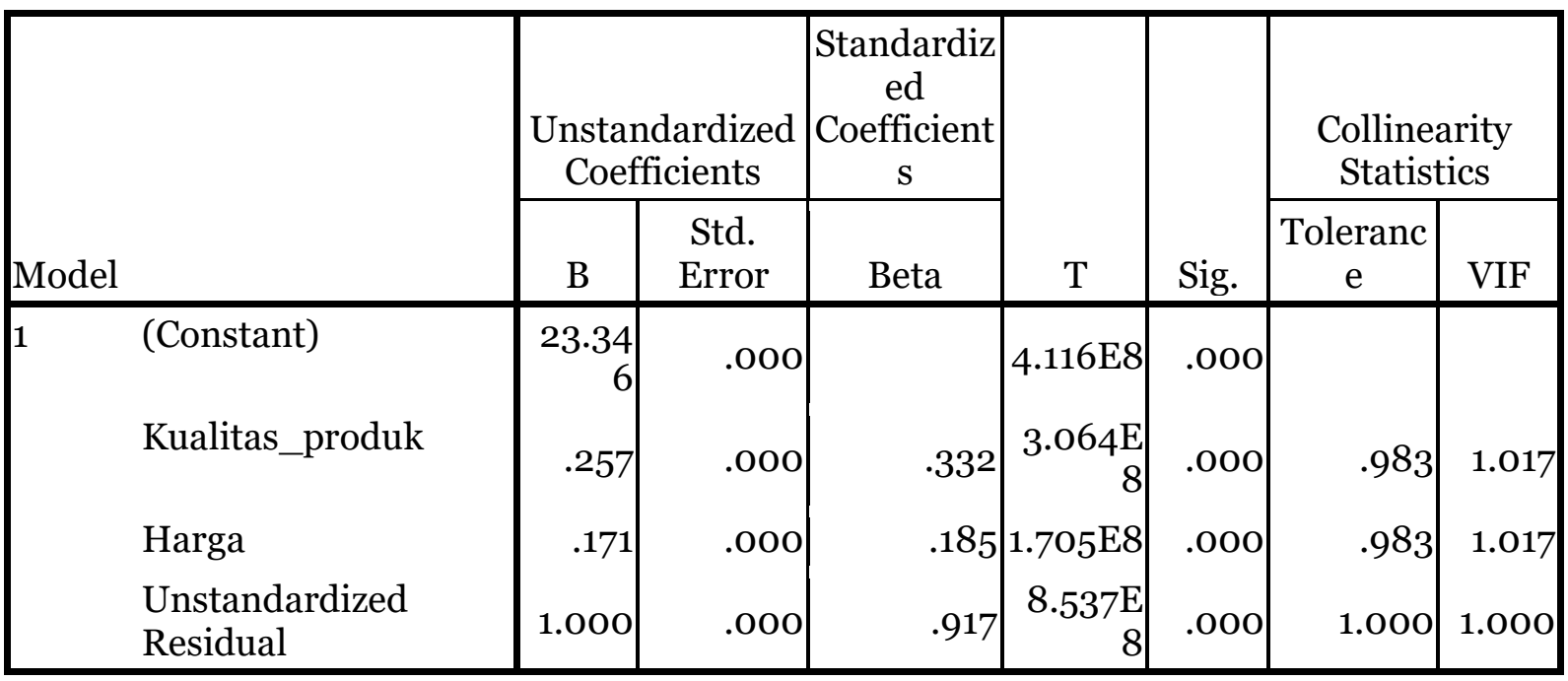

a. Dependent Variable: Loyalitas

Sumber : Data penelitian, diolah

Berdasarkan Tabel 2 diatas, diketahui bahwa nilai Tolerance kedua variabel lebih dari o,10 dan VIF kurang dari 10. Maka dapat disimpulkan bahwa tidak terjadi multikolinearitas antar variabel bebas.

\section{Uji Heteroskedastisitas}

Regresi yang baik seharusnya tidak terjadi heteroskedastisitas. Heteroskedastisitas berarti bahwa varian residual yang tidak sama pada semua pengamatan di dalam model regresi. Uji heteroskedastisitas dalam penelitian ini menggunakan metode korelasi Spearman's rho. Teknik uji koefisien korelasi Spearman's rho yaitu mengorelasikan variabel independen dengan residualnya. Hasil uji heteroskedastisitas dapat dilihat pada tabel dibawah ini.

Tabel 3. Hasil Uji Heteroskedastisitas 


\section{Correlations}

\begin{tabular}{|c|c|c|c|c|c|}
\hline & & & $\begin{array}{c}\text { Kualitas_pro } \\
\text { duk }\end{array}$ & Harga & $\begin{array}{l}\text { Unstandardiz } \\
\text { ed Residual }\end{array}$ \\
\hline \multirow[t]{9}{*}{$\begin{array}{l}\text { Spearman's } \\
\text { rho }\end{array}$} & \multirow[t]{3}{*}{ Kualitas_produk } & $\begin{array}{l}\text { Correlation } \\
\text { Coefficient }\end{array}$ & 1.000 & .232 & -.012 \\
\hline & & Sig. (2-tailed) & & .109 & .936 \\
\hline & & $\mathrm{N}$ & 49 & 49 & 49 \\
\hline & \multirow[t]{3}{*}{ Harga } & $\begin{array}{l}\text { Correlation } \\
\text { Coefficient }\end{array}$ & .232 & 1.000 & .103 \\
\hline & & Sig. (2-tailed) & .109 & & .483 \\
\hline & & $\mathrm{N}$ & 49 & 49 & 49 \\
\hline & \multirow[t]{3}{*}{$\begin{array}{l}\text { Unstandardized } \\
\text { Residual }\end{array}$} & $\begin{array}{l}\text { Correlation } \\
\text { Coefficient }\end{array}$ & -.012 & .103 & 1.000 \\
\hline & & Sig. (2-tailed) & .936 & .483 & \\
\hline & & $\mathrm{N}$ & 49 & 49 & 49 \\
\hline
\end{tabular}

Sumber : Data Penelitian, diolah.

Berdasarkan hasil output pada tabel diatas dapat diketahui bahwa korelasi antara variabel kualitas produk dan harga dengan unstandardized residual memiliki nilai signifikansi (sig 2 tailed) lebih dari 0,10. Karena nilai signifikansi lebih besar dari o,10 dapat disimpulkan bahwa tidak terjadi masalah heteroskedastisitas.

\section{Hasil Estimasi}

Estimasi model dilakukan untuk melihat pengaruh variabel kualitas produk dan harga terhadap loyalitas konsumen Tupperware. Metode yang digunakan yaitu regresi linier berganda. Adapun hasil pengolahan data yang dilakukan dapat dilihat pada tabel berikut.

Tabel 4. Hasil Estimasi

\section{Coefficients $^{\text {a }}$}

\begin{tabular}{|c|c|c|c|c|c|c|c|c|}
\hline \multirow{2}{*}{\multicolumn{2}{|c|}{ Model }} & \multicolumn{2}{|c|}{$\begin{array}{c}\text { Unstandardized } \\
\text { Coefficients }\end{array}$} & \multirow{2}{*}{$\begin{array}{c}\text { Standardized } \\
\text { Coefficients } \\
\text { Beta } \\
\end{array}$} & \multirow[b]{2}{*}{$\mathrm{t}$} & \multirow[b]{2}{*}{ Sig. } & \multicolumn{2}{|c|}{$\begin{array}{c}\text { Collinearity } \\
\text { Statistics } \\
\end{array}$} \\
\hline & & B & Std. Error & & & & $\begin{array}{c}\text { Toleranc } \\
\mathrm{e}\end{array}$ & VIF \\
\hline \multirow[t]{3}{*}{1} & (Constant) & 23.346 & 7.139 & & 3.270 & .002 & & \\
\hline & $\begin{array}{l}\text { Kualitas_prod } \\
\text { uk }\end{array}$ & .257 & .105 & .332 & 2.434 & .019 & .983 & 1.017 \\
\hline & Harga & .171 & .126 & .185 & 1.355 & .182 & .983 & 1.017 \\
\hline
\end{tabular}

a. Dependent Variable:

Loyalitas 
Sumber : Data Penelitian, diolah.

Berdasarkan tabel diatas maka persamaan analisis regresi linier berganda dalam penelitian ini sebagai berikut.

$$
\begin{aligned}
& \text { Loyalitas }=\beta_{\mathbf{o}}+\beta_{1} \text { Kualitas }+\beta_{2} \text { Harga }+e \\
& \text { Loyalitas }=\mathbf{2 3 , 3 4 6}+\text { o,257Kualitas }+ \text { o,171Harga }+ \text { 7,139 }
\end{aligned}
$$

Dari persamaan diatas, hasil yang dapat dijelaskan sebagai berikut :

1. Nilai konstanta sebesar 23,346 , artinya jika variabel kualitas produk dan harga bernilai o, maka loyalitas konsumen Tupperware nilainya sebesar 23,346.

2. Koefisien regresi variabel kualitas produk nilainya 0,257 . Hal ini menunjukkan bahwa setiap kenaikan kualitas produk sebesar 1 satuan dengan asumsi variabel harga tetap, maka loyalitas konsumen akan meningkat sebesar 0,25 persen. Tanda (+) menunjukkan adanya hubungan yang searah antara kualitas produk dengan loyalitas konsumen.

3. Koefisien regresi variabel harga nilainya 0,171. Hal ini menunjukkan bahwa setiap kenaikan harga sebesar 1 satuan dengan asumsi variabel kualitas produk tetap, maka loyalitas konsumen akan meningkat sebesar 0,17 persen. Tanda $(+)$ menunjukkan adanya hubungan yang searah antara harga dengan loyalitas konsumen.

\section{Koefisien Determinasi $\left(\mathbf{R}^{2}\right)$}

Koefisien determinasi digunakan untuk melihat seberapa besar pengaruh variabelvariabel independen terhadap variabel dependen. Nilai koefisien determinasi ditentukan dengan nilai adjusted R-Square.

Berdasarkan hasil estimasi diperoleh nilai R-Squared sebesar 0.516. Hal ini menunjukkan bahwa variasi loyalitas konsumen Tupperware mampu dijelaskan oleh kualitas produk dan harga sebear 51 persen. Sedangkan sisanya sebesar 49 persen dipengaruhi oleh variabel lain yang tidak digunakan dalam penelitian ini. Hasil uji koefisien determinasi penelitian ini dapat dilihat pada tabel berikut.

\section{Tabel 5. Koefisien Determinasi $\left(\mathbf{R}^{2}\right)$}

\section{Model Summary ${ }^{b}$}

\begin{tabular}{|l|r|r|r|r|}
\hline Model & R & \multicolumn{1}{|c|}{ R Square } & Adjusted R Square & Std. Error of the Estimate \\
\hline 1 & $.640^{\mathrm{a}}$ & .516 & .412 & 2.57820 \\
\hline
\end{tabular}

a. Predictors: (Constant), Harga, Kualitas_produk

b. Dependent Variable: Loyalitas

Sumber : Data Penelitian, diolah

\section{Pengujian Hipotesis}




\section{Uji t}

Uji t digunakan untuk menguji variabel-variabel independen terhadap variabel dependen secara parsial. Derajat signifikansi yang digunakan dalam penelitian ini adalah $\alpha=0.10, \mathrm{df}=$ 46 (1.67252) untuk membandingkan nilai t-tabel dengan nilai t-statistik. Hasil uji t dapat dilihat pada tabel dibawah ini.

Tabel 6 : Hasil Uji t-statistik

\begin{tabular}{ccccc}
\hline Variabel & t-statistik & t-tabel & Prob. & Kesimpulan \\
\hline Kualitas Produk & 2.434 & 1.67252 & 0.019 & Signifikan \\
\hline Harga & 1.355 & 1.67252 & 1.182 & Tidak Signifikan \\
\hline
\end{tabular}

Sumber : Data Penelitian, diolah

Berdasarkan Tabel 4. diatas diketahui bahwa nilai t-statistik variabel kualitas produk lebih besar dibandingkan dengan nilai t-tabel atau 2,434 $>1,67252$. Hal ini berarti bahwa kualitas produk berpengaruh signifikan secara parsial terhadap loyalitas konsumen Tupperware. Sedangkan variabel harga memiliki nilai t-statistik yang lebih kecil dibandingkan dengan nilai t-tabel atau $1,355<1,67252$. Hasil ini berarti bahwa harga tidak signifikan berpengaruh terhadap loyalitas konsumen Tupperware.

\section{Uji F}

Uji F bertujuan untuk mengetahui pengaruh variabel independen secara bersamasama terhadap variabel dependen. Langkah yang harus dilakukan dalam uji $\mathrm{F}$ adalah dengan membandingkan nilai F-statistik dengan nilai $\mathrm{F}$ tabel. Berdasarkan hasil estimasi diperoleh nilai $F$ statistik sebesar 4,380 dan nilai $F$ tabel sebesar 2,42 dengan nilai df $(2,47)$. Nilai $F$ statistik lebih besar dibandingkan dengan nilai $\mathrm{F}$ tabel atau 4,380 $>2,42$. Dengan demikian dapat disimpulkan bahwa kualitas produk dan harga secara bersama-sama berpengaruh terhadap loyalitas konsumen Tupperware.

Hasil estimasi menunjukkan bahwa variabel kualitas produk memiliki hubungan yang positif dan signifikan terhadap loyalitas konsumen Tupperware. Hubungan ini sesuai dengan hipotesis awal yang menyatakan bahwa kualitas produk memiliki hubungan yang positif dengan loyalitas konsumen. Hal ini menunjukkan bahwa semakin baik kualitas produ-produk Tupperware maka konsumen akan semakin loyal untuk menggunakan produk Tupperware.

Menurut Dharmamesta, loyalitas konsumen dipengaruhi oleh kualitas produk dan promosi (Dharmamesta dan Swasthu, 1999). Perusahaan yang sangat memperhatikan kualitas produk dan menawarkan harga yang sangat wajar akan lebih mudah mendapatkan konsumen yang loyal. Karena kualitas produk yang baik akan memberikan kepuasaan konsumen yang 
tinggi. Dengan demikian, produk yang mampu memberikan kepuasan kepada konsumen akan lebih mudah memperoleh konsumen yang memiliki loyalitas yang tinggi.

Kualitas produk dinilai sebagai nilai lebih dari Tupperware yang membuat konsumen selalu setia menggunakan produknya. Selain itu, berbagai desain dan warna yang menarik juga menjadi point penting yang meningkatkan loyalitas konsumen Tupperware.

Produk yang dipasarkan akan memenangkan persaingan pasar jika produk tersebut memiliki mutu atau kualitas yang tinggi. Sebaliknya, produk dengan kualitas yang rendah akan memperolh citra yang tidak baik dari konsumen. Sebagimana firman Allah SWT dalam Q.S AlBaqarah : 168.

Artinya : "Hai sekalian manusia, makanlah yang baik lagi halal dari apa yang terdapat di bumi, dan janganlah kamu mengikuti langkah-langkah syaitan; karena sesungguhnya syaitan itu adalah musuh yang nyata bagimu”.

Hasil estimasi juga menunjukkan bahwa variabel harga memiliki hubungan yang positif tetapi tidak signifikan mempengaruhi loyalitas konsumen Tupperware. Hasil estimasi ini tidak sejalan dengan hipotesis awal yang menyatakan bahwa variabel harga berpengaruh positif dan signifikan terhadap loyalitas konsumen. Hal ini menandakan bahwa berapapun harga yang ditawarkan Tupperware tidak akan mempengaruhi loyalitas konsumen Tupperware.

Secara parsial, variabel harga tidak signifikan mempengaruhi loyalitas konsumen Tupperware. Berdasarkan hasil uji t, dimana nilai t-statistik lebih kecil dibandingkan nilai ttabel atau 1,355 < 1,67252.

Perusahaan dalam menetapkan harga harus mempertimbangkan faktor-faktor dalam menentukan kebijakan penetapan harga. Dengan demikian, harga yang ditawarkan dapat diterima oleh masyarakat. Konsumen dalam mempersepsikan harga dilihat dari beberap hal diantaranya ; terjangkau atau tidaknya harga, kesesuaian harga dengan kualitas produk dan kesesuaian harga dengan kuantitas.

Menurut ibnu Qudamah al-Maqsidi, bahwa pemerintah tidak memiliki wewenang untuk mengatur harga bagi penduduk. Penduduk boleh menjual barang-barang mereka dengan harga berapan pun yang mereka sukai. Argumen tersebut didasarkan kepada hadist yang diriwayatkan oleh Imam Abu Daud. Imam Abu Daud meriwayatkan dari Abu Hurairah yang mengatakan "bahwa ada seseorang laki-laki datang lalu berkata, "Wahai Rasulullah SAW tetapkanlah harga ini. "(Tidak) justru , biarkan saja” Kemudian beliau didatangi laki-lai yang lain lalu mengatakan, "wahai Rasulullah SAW, tetapkanlah harga ini. Beliau mengatkan, "(Tidak) tetapi Allah lah yang berhak menurunkan dan menaikkan". 
Berdasarkan hal tersebut diatas, dapat disimpulkan bahwa harga boleh ditetapkan sendiri. Harga yang tinggi muncul pada dasarnya bermula dari tingginya permintaan atau penawaran yang menurunterhadap barang tersebut.

Variabel harga yang tidak signifikan mempengaruhi loyalitas konsumen Tupperware manunjukkan bahwa produk-produk Tupperware sudah mendapatkan posisi istimewa di hati konsumennya. Produk-produk Tupperware selama ini dikenal memiliki harga yang relatif tinggi untuk kategori peralatan rumah tangga berbahan plastik. Tetapi harga yang dinilai mahal oleh konsumen ini tidak menurunkan tingkat loyalitas konsumen untuk tetap setia menggunakan berbagai produknya.

PT. Pegadaian Indonesia yang memutuskan untuk menerima Tupperware untuk digadaikan menjadi terobosan terbaru dalam persaingan produk rumah tangga berbahan plastik. Produk Tupperware bisa digadaikan dengan kategori pinjaman gadai kecil. Konsumen Tupperware mulai saat ini tidak hanya bisa mendapatan manfaat produk sebagai peralatan rumah tangga tetap juga bisa digunakan mendapatkan pinjaman gadai.

\section{KESIMPULAN}

Berdasarkan hasil penelitian dan pembahasan diatas, maka dapat disimpulkan bahwa secara parsial faktor yang mempengaruhi loyalitas konsumen Tupperware dan berpengaruh secara positif yaitu kualitas produk. Sedangkan variabel harga tidak signifikan mempengaruhi loyalitas konsumen Tupperware. Secara simultan, variabel kualitas produk dan harga secara bersama-sama mempengaruhi loyalitas konsumen Tupperware.

Peningkatan loyalitas konsumen Tupperware dapat dilakukan dengan beberapa cara yaitu : (1) Mempertahankan kualitas produk , (2) meningkatkan kreativitas dalam desain yang lebih menarik agar tetap mampu bersaing dengan merek-merek lain yang menjadi pesaingnya.

\section{DAFTAR PUSTAKA}

Arikunto, Suharsimi, 2006, Prosedur Penelitian Suatu Pendekatan Praktek, Jakarta: PT. Rineka Cipta.

Basu, Swastha, 2009. Azaz-azaz Marketing, Yogyakarta : Liberty.

Departemen Agama Republik Indonesia, 2007, Al-Qur'an dan Terjemahnya, Bogor : SYGMA.

Dharmamesta, dan Swasthu, Basu, 1999, Loyalitas Pelanggan : Sebuah kajian konseptual sebagai panduan bagi peneliti. Jurnal ekonomi dan bisnis Indonesia, Vol. 14No. 3 Tahun 1999.

Gozali, Imam, 2001, Aplikasi Analisis Multivariate Dengan SPSS. Edisi kedua, Semarang : Badan Penerbit Universitas Diponegoro. 
Jajuli, M, Jajuli, 2016, Ekonomi Islam Umar bin Khattab, Yogyakarta : Deepublish.

Kotler, Philip dan Gary Amstrong. 2000, Pinsip-Prinsip Pemasaran, Jakarta : Erlangga.

Kurniawan, Rakhman, Arief, 2014, Total marketing, Yogyakarta : Kobis.

Movanita, Kemala, Nadia, Ambaranie, 2018, PT. Pegadaian Menerima Tupperware untuk Digadai, Bunganya Nol Persen., www.ekonomi.kompas.com. Diakses 23 Agustus 2018, Pukul 20.23 WIB.

Tupperware, 2018, Penghargaan Tupperware . www.Tupperware.co.id. Diakses 24 Agustus 2018, Pukul 14.00 WIB.

Yazia, Vivil, 2014. Pengaruh Kualitas Produk, Harga dan Iklan Terhadap Pembelian Handphone Blackberry, dalam Jurnal Program Studi Pendidikan Ekonomi STKIPPGRI Sumatera Barat, volume 2, No. 2, Mei 2014. 